\title{
SANTOS Y VÍRgENES ENTRE SUEÑOS. RELATOS ONÍRICOS DE PEREGRINOS Y DEVOTOS \\ DEL SUR ANDINO DE PERÚ
}

\author{
Saints and Virgins among Dreams. \\ Dream Stories of Pilgrims and Devotees \\ of the Southern Andes of Peru
}

Vicente Torres Lezama ${ }^{1}$

Resumen: El objetivo del presente trabajo es mostrar cómo se entiende el sueño, musqhoy, entre los pobladores quechuas del sur de Perú, para seguidamente describir el sueño de devotos y peregrinos, mediante qué revelaciones reciben y cómo responden a estas manifestaciones oníricas estas personas. Me acerco al tema a través de diálogos y entrevistas realizadas a danzantes, mayordomos y devotos de distintas provincias de Cuzco, y por mis propias experiencias de peregrino danzante; además, para ampliar la discusión, me apoyo en las etnografías del sueño de la región y de otros departamentos del país. Inicio el tema con las categorías y nociones locales con las que se entiende el sueño entre los pobladores andinos, en el que la palabra "sueño" no implica dormir, como ocurre en español; esta acción de dormir es entendida por los quechuas como algo "externo" que conduce al cuerpo a dormir. Siguiendo el entendimiento local del sueño, me detengo en la expresión sut'ipi hina —en verdad/realidad—y musqhoypi hina —en sueño—, que no son antagónicos, sino análogos, ya que los acontecimientos

\footnotetext{
${ }_{1}^{1}$ Antropólogo quechua, profesor de la Universidad Nacional de San Antonio Abad del Cuzco —UNSAAC_, maestro y candidato a doctor por la Universidad Iberoamericana de México. Orientado al estudio de fiestas, peregrinaciones y rituales de los Andes peruanos.

Correo electrónico: vtorreslezama@gmail.com

Fecha de recepción: 2707 17; Fecha de aceptación: 251017.
}

(cc) EY-NC-ND Páginas 117-146. 
inexplicables en la vida pueden ser referidos como "en sueño", y una serie de imágenes en los sueños pueden vivirse como "en verdad/ realidad". Organizo el trabajo en tres secciones: expresiones quechuas sobre el sueño; el sueño con entidades, santos y vírgenes; e ideas finales.

Palabras clave: sueño, Andes, devotos, entidades, danzantes, peregrinos.

Abstract: The objective of the present work is to show how dream or musqhoy is understood among the Quechua inhabitants of southern Peru, in order to describe the dream of devotees and pilgrims, and at the same time to show the revelations they receive and they respond to these dream manifestations. I approach the subject through dialogues and interviews with dancers, mayordomos and devotees of different provinces of Cuzco, as well as to my own experiences as dancing pilgrim; In addition, to broaden the discussion, I appeal to the dream ethnographies of the region and other departments of the country. I start the subject by showing the local categories and notions with which the dream is understood among the Andean inhabitants, to whom the word dream does not imply sleeping as it does in spanish, but this sleeping action is understood by the Quechua as something "external" that leads the body to sleep. Following the local understanding of the dream, I dwell on the expression sutipi hina — in truth/reality - and musqhoypi hina —in sleep-, which are not antagonistic, but analogical; as inexplicable events in life can be referred to as "in dream" and a series of images in dreams can be lived as "in truth/reality". I organize the work in three sections: Quechua expressions on sleep, sleep with entities, saints and virgins and final ideas.

Keywords: sleep, Andes, devotees, entities, dancers, pilgrims. 
Mapa 1. Mapa de Cuzco y sus provincias. Las provincias que llevan el recuadro son las que conforman las naciones peregrinas del santuario de Qoyllurit'i. A estas ocho naciones se han incorporado peregrinos de otros pueblos.

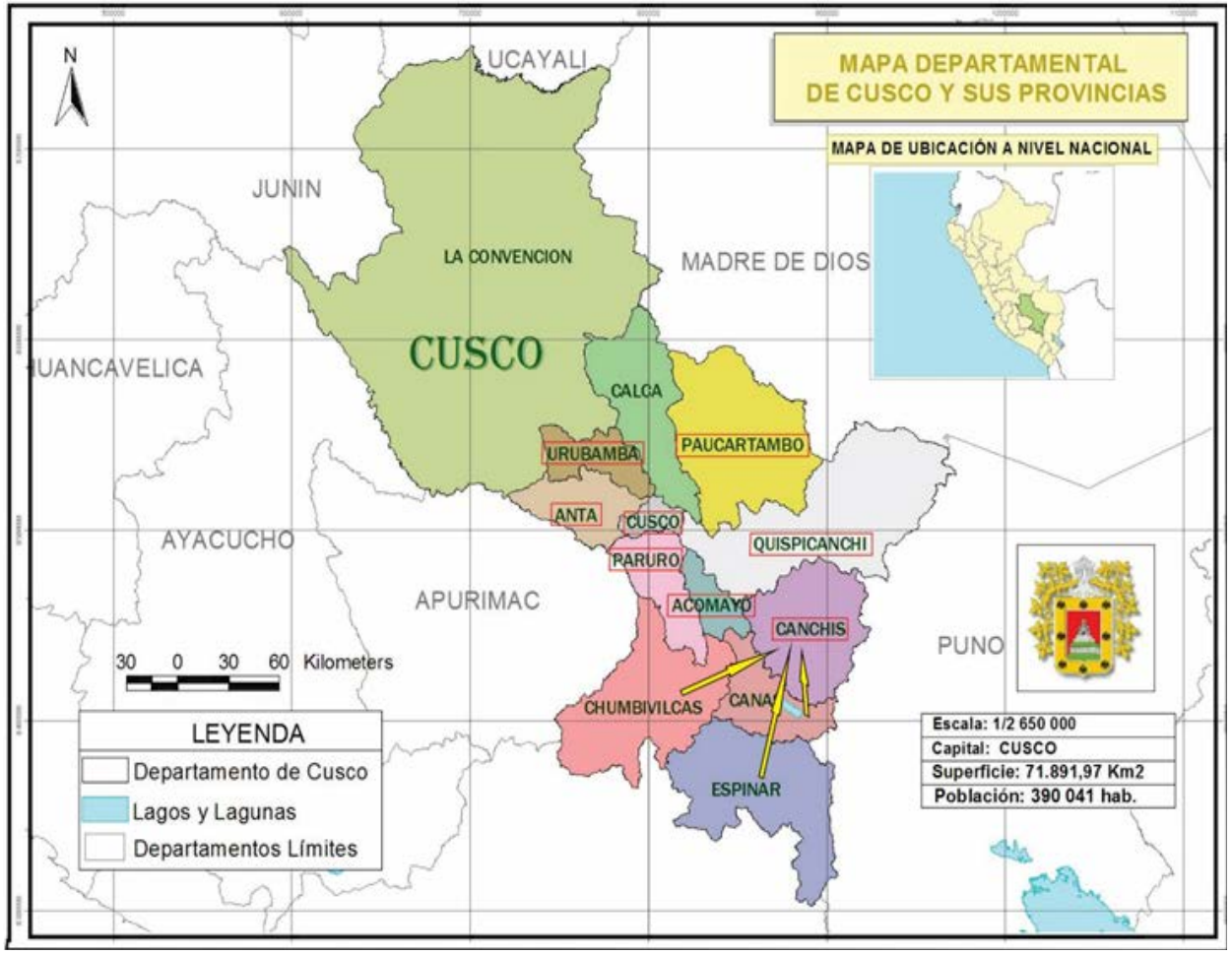

Fuente: http://190.223.52.140/siarcusco/index.php (consultado en 2013)

\section{Expresiones quechuas sobre el sueño}

En este primer apartado abordaré las distintas expresiones locales del sueño, principalmente de la región de Cuzco. Tomando las palabras de Marylin Strathern (1988), "para no caer en el equivoco cultural de interpretación" es indispensable alejarse del entendimiento de que la buena descripción está basada en la teoría, es decir, en algún cuerpo de ideas subyacentes que proporcionan una razón para aceptarlas. En ese sentido, no se proporciona la comprensión de cómo esto fue visto por los involucrados, sino de cómo el investigador, a partir de sus supuestos, construye la interpretación de esa realidad. Así, Strathern considera que el lenguaje analítico parece crearse a sí mismo cada vez 
como más complejo y más distante de las realidades de esos mundos que procura retratar, peor aún, sin tomar en consideración el lenguaje de los pueblos o sociedades que describe. De este modo, indica que los valores, ideas y representaciones son contextualizados localmente; por tanto, la descontextualización no funciona. Pero no se trata de sustituir conceptos exógenos por contrapartes nativos, la tarea es transmitir la complejidad de los conceptos nativos refiriéndolos al contexto particular en el que son producidos. Consecuentemente, tomaré en cuenta las expresiones locales sobre el sueño para sugerir la comprensión de los mismos.

Por un lado, la palabra quechua "musqhoy" hace referencia al sueño o a las imágenes que se tiene en los sueños, a diferencia del español, la palabra no implica la idea de dormir; "puñuy" es la palabra que hace alusión a la acción de dormir. Así, cuando una persona tiene sueño, en quechua se dice: puñuy aysawashan — me lleva el sueño o me jala el sueño_-, como si la acción de dormir fuera una "entidad" aparte que domina y lleva al cuerpo. Se usan distintas frases para hacer referencia a este mismo hecho, por ejemplo: puñuy atiyuwashan — me vence el sueño-, puñuy mat'iyuwashan — me presiona el sueño- o misk'ita puñuy atiywashan —el sueño me vence dulcemente-. Con frecuencia se oye decir: manan puñuytaqa atiparuwaqchu, kallpayuqmi —no puedes dominar al sueño, tiene fuerza—, sobre todo cuando ocurren accidentes automovilísticos en el que el conductor se duerme. Asimismo, cuando se siente sueño se dice: puñunaywashan — tengo ganas de que me lleve el sueño-, el tener sueño es como el tener ganas de "eso", eso que te domina o te lleva a fuerza cual si fuera una "entidad" aparte. Es decir, que la persona no siente ganas de dormir como una necesidad biológica del cuerpo, sino que sus ganas de dormir proceden de otra parte. Por el contrario, cuando no se tiene sueño se dice: mana puñuy aysawanchu — no me jala o lleva el sueño-; y cuando se intenta dormir y no se logra, se dice: puñuymanayuni — pero el sueńo no le

\footnotetext{
${ }^{2}$ En el Cuzco prehispánico había un santuario, en el sistema de ceques del Cuzco, conocido como Puñui, era el segundo santuario que estaba asociado con el sueńo. En este santuario se hacían rituales para acceder a un buen sueño y no morir durmiendo (AMLQ, 1995: 412; Bauer, 2016: 74). De manera que los sueńos tuvieron relevancia en la vida de los pobladores andinos del periodo prehispánico como la tiene en la actualidad.
} 
lleva-. En tanto que a la persona que duerme mucho se la conoce como puñuy siki, donde puñuy es dormir y siki, trasero - literalmente se diría "trasero dormido".

Por otro lado, cuando los pobladores duermen y no recuerdan nada del sueño que tuvieron, se dice: ch'akita puñurapusqani - me dormí seco-o chuchuta puñurusqani — me dormí duro-, mana ima mosqhokusqaytapas yuyanichu — no recuerdo nada de lo que soñé-. Este dormir profundo se suele dar cuando los pobladores sienten fuerte cansancio, sayk'uy, por el trabajo y duermen hasta no recordar nada, muy similar a la idea de beber mucho y no recordar nada. También hay expresiones como: musqhoykusparaq puñuyapushasqani illarimuykama - hasta el amanecer me había quedado dormido sońando-, cuando se duerme con satisfacción y el sueño acompaña este descanso; por eso dicen: mishk ita puñuyapushasqani — estaba durmiendo dulcemente.

En este dormir agradable en el que el sueño se produce, las personas que sueñan cuentan sus sueños comenzando con una frase: millayta musqhokuni —me soñé bien feo- o munayta musqhokuni —soñé lindo-; es decir, que los sueños son vistos como feos o bonitos antes que como malos o buenos. Los sueños feos por lo común preocupan al soñante y a veces a la familia entera, porque anuncian un porvenir difícil. Por ejemplo, Luis F. Andrade (2005) muestra el caso de Ana María, madre soltera con varios hijos, que atraviesa una crisis y busca comunicarse con su hermana que migró a Argentina, pero no lo logra. Ana María decide hablar con la foto de su madre y le pide ayuda entre lágrimas; después de dos días sueńa con su madre que la consuela y le dice que todo tiene solución. Y pasado algunos días recibe la llamada de su hermana de Argentina, quien le dice: "A papá y a mamá les he sońado bien feo y ya dije que algo te ha pasado" (Andrade Ciudad, 2005: 59), a partir de entonces Ana María asume que soñar con su madre es favorable para ella porque luego de que su hermana soñara con sus padres decidió llamarla para saber su situación y ayudarla a salir de su problema. En tanto que su hermana refiere a un sueño "bien feo" con sus padres.

Ejemplo de otro sueño feo es uno propio que muestro a continuación, cuando era estudiante de secundaria soñé que viajaba con mi 
familia en un bus que iba hacia abajo sobre pajonales, y en el trayecto el carro pisaba las papas menudas que estaban esparcidas en el suelo. Conté este sueño a mi madre y ella me dijo: ichhuqa waqanapaq - la paja es para llorar-, carruqa cajunpaq —el carro para cajón-, papataq wañukpa uman — y la papa es la cabeza de un muerto-. Pasado un tiempo de mi sueño mi padre falleció. Antes de que este acontecimiento se diera mi madre y mi hermana habían sentido en su descanso la presencia del alma que las aplastaba — alma ñit'iruwan-. Describían esta alma como un bulto que las aplastaba y ellas luchaban para liberarse. Al contar su pesadilla la respuesta que recibieron fue: wañuqcha kanqa — habrá muerto- Ahora bien, de acuerdo con Bruce Mannheim (2015: 15), en Andahuaylillas _Cuzco-, "las predicciones de los sueños son sólo válidas durante el día en que han sido soñadas". No comparto este punto de vista porque hay sueños premonitorios que no necesariamente se restringen al día siguiente, como ocurrió con los míos. Así también sostiene Luis Andrade para el caso de Pampas, dice: "Esta limitación temporal es muy rara. En Pampas, y entre los migrantes entrevistados en Lima, el evento anunciado por el sueño puede demorar en concretarse desde más de un día hasta varios años" (Andrade Ciudad, 2005: 57).

Continuando con los sueños feos — sangre, sacarse el diente, agua turbia, papa, santos y vírgenes, etc.-, para contrarrestar e impedir sus consecuencias se realizan diversas acciones. Por ejemplo, antes de contar el sueño feo los pobladores sugieren voltear la ropa interior - t'ikranayki p'achaykita - para que se revierta lo sońado. Otros sugieren que es bueno golpear la almohada por tres veces. También, "cuando un mal presagio aparece en un sueńo, uno se levanta primero con el pie izquierdo. Antes de conversar con alguien sobre el mal augurio uno tiene que buscar una oveja o llama joven, contarle todo el sueño y luego escupir en su boca tres veces diciendo: 'qullu, qullu, qullu' - 'que no ocurra, que no ocurra, que no ocurra'-” (Mannheim, 2015: 15). "Según las mujeres de Chihua y de Contay, para anularlos, se debe contar de inmediato el sueńo a alguien. No es necesario que sea una persona, también se puede contar a un animal, o insultar si en el mal sueño destaca un objeto particular o un lugar" (Cecconi, 
2013: 163). De modo semejante, cuando se sueña con un perro se debe contar de inmediato al perro antes de hacerlo a alguna persona porque el perro es considerado como el "alma del ladrón". Estas acciones son necesarias debido a que, para muchos, los sueños se cumplen: sut'inchakun, y éstas son maneras de evitar sus consecuencias. Ahora bien, además del sueño, hay diversas manifestaciones qhencha — de mal augurio- que acompañan a las premoniciones feas y que ayudan a validar el sueño. Por ejemplo, cuando una persona va a morir se siente el olor a vela, el olor a zorrino, el canto del búho en el techo de la casa, la presencia de la mariposa negra, etc., con todo ello el sońante predice con claridad la muerte de algún familiar o amigo cercano. Por tanto, al sueño feo le acompañan otras manifestaciones que corroboran su cumplimiento, sobre todo en este caso de la muerte.

Otro aspecto de los sueños es el llamado sut'inchakuy o el hecho de que el sueño se concreta en la realidad o se hace verdad. Noqaqa sut 'inchakuytan yachani —a mí el sueño se me cumple— suelen decir aquellos a quienes el sueño se les hace verdad. Sut'ipi hinaraq es otra expresión que se dice cuando el sueño se vive como en vigilia o como en la realidad. Por consiguiente, sueño y realidad no son antagónicos, sino análogos. Así como el sueño se vive como en la realidad, también la realidad se vive como en el sueño: musqhoypi hinaraq. Además, tanto el musqhoy — sueño— como el sut' $i$ — verdad/realidad— se imbrican porque son difusas sus fronteras. "Las memorias diurnas y nocturnas se entremezclan y se apoyan mutuamente" (Cecconi, 2013: 182). Y "siglos después de producida la conquista española, los sueños siguen siendo 'verdad' para los pobladores de los Andes, en el sentido de que tienen cosas muy concretas que decir acerca de los avatares de la vida diaria, sobre el amor, la muerte y los pesares" (Andrade Ciudad, 2005: 32). Ejemplos de cómo se vive la realidad como en sueño, musqhoypi hinaraq, son recogidos por la Comisión de la Verdad y Reconciliación (CVR) de las víctimas de la violencia interna en el país. Dice uno de los testimonios: "Sueñopi hinan qarccani, 'estaba como en sueño. ... durante todo ese tiempo estuve dormida, casi desde el ańo 92 hasta el 98 es como si hubiera estado dormida, era todo una pesadilla' " (testimonio en CVR; citado por Cecconi y Crisóstomo, 2007: 72). Del 
mismo modo, se puede tener un sueño, sut'ipi hinaraq, como realidad. Es cuando el soñante parece estar viviendo una experiencia real mientras duerme: se alegra, llora, ora, se preocupa y hasta siente dolores reales cuando despierta. El sueño es tan parecido a la vivencia en la vigilia que se considera que se está despierto. De la misma manera, cuando se vive una realidad tan ardua o poco familiar se la considera estar en sueño. Es así, que cuando se dice alguna cosa incoherente los pobladores suelen decir: ¿musqhokushankichu?, iyuyaynikipichu kashanki! —¿te estás soñando?, ¡estás en tu sentido!- - También se pregunta: ¿mosqhoypichu, sut 'ipichu? - ¿en sueño o en verdad/vigilia? - cuando se recibe una noticia extraña.

Asimismo, es indispensable señalar otras frases que se refieren frecuentemente entre los pobladores andinos: puñuy puñuy, musqhoyta hap'iy y musphay. Puñuy puñuy hace alusión al estado de semi-vigilia, en este estado uno puede tener sueños reveladores, pero también sueños poco reveladores. Mientras que musqhoyta hap 'iy ${ }^{3}$ - atrapar el sueño- se refiere al sueño en el sueño; es decir, el soñante se da cuenta de que las imágenes que visualiza son un sueño, se da cuenta dentro del mismo sueño y mientras duerme. Musphay se podría traducir como "sonámbulo", un estado en el que la persona tiene pesadillas como consecuencia de acciones fuertes que impactan al ser en la vigilia, algunas veces se relaciona con el susto, mancharisqa. Con frecuencia se puede ver este hecho en nińos y jóvenes, que entre dormidos suelen levantarse y caminar en alguna dirección, llorar, hablar, o brincar mientras duermen. ${ }^{4}$ Una de las recetas para resolver el hecho es hacerles comer papa nativa conocida como araq papa; esta papa se coce en la brasa, kusaruspa, y luego se le da de comer al musphapakuq —al que sufre de sonámbulo- . También se les hace para curar de susto, si es el caso.

Con estas expresiones quechuas he querido mostrar brevemente la complejidad que implica el soñar. Sin embargo, no voy a entrar en más detalles porque el objetivo de este trabajo es presentar diversos testimonios de peregrinos y devotos relacionados con santos y vírgenes en los Andes.

\footnotetext{
${ }^{3}$ La expresión es usada en Apurimac, comentado por Yeny Cereceda.

4 "brincar mientras duermen" es referido en quechua como pachan wikch' uwan, y se da cuando la tierra toma la fuerza vital de una persona provocando este sobresalto.
} 


\section{El sueño con entidades, santos y vírgenes}

En esta sección mostraré cómo los pobladores andinos sueñan con los Apu, la Pachamama, los santos y las vírgenes. Antes de ir a los relatos del sueño es importante indicar que una persona no sueña al santo, la virgen, al Apu — montaña - y la Pachamama -Madre Tierra-, sino que "el santo te/le sueña”; la expresión quechua es: Taytacha musqhoychawan me soñó el santo-; mamacha musqhoychawan —me soñó la virgen-, expresiones similares a la idea de que "me habló". Quienes hablan español narran su sueño con la siguiente expresión: "me reveló la virgen". Sin embargo, no es el mismo santo o virgen el/la que sueńa a los devotos, es decir, la efigie, sino que el santo toma diferentes formas o personajes como policías, militares, mujeres y niños. Esto mismo refieren Kato (2001) y Valencia (2007) sobre las formas en que el Niño Compadrito aparece en los sueños. Así, el Niño se presenta en los sueños como de entre 8 y 10 años, niño harapiento, niño urbano, de guardia civil de 20 a 25 años, de policía atento y carińoso, de geniecillo, de médico, de abogado, como compadre mestizo, de padre, de anciano, de universitario, de muchacha. Es decir, el niño puede tomar la apariencia de un viejo o joven, hombre o mujer, de clase alta o baja, etc. (Kato, 2001: 108-109). Así, siguiendo el argumento de Pedro Pitarch (2013), la identidad de los santos y vírgenes en los sueños es inestable, discontinua, heterogénea y no absoluta. No obstante, sońar con el bulto del santo o virgen es qhencha, de mal augurio, representa desgracia o muerte.

Del mismo modo, los Apu — montaña_y la Pachamama — Madre Tierra - se aparecen en los sueños como personas; por ejemplo, para que un paqo, especialista ritual, realice haywarisqa o alcance -ofrenda- sueña con una mujer desnuda, esta mujer es la Pachamama. Así, el territorio andino es espiritualmente antropomorfo y activo; no simboliza humanidad, como se sostiene desde la visión occidental, sino que esconde bajo su envoltura de montańa y tierra una espiritualidad humana capaz de actuar e interactuar con los pobladores andinos. Además, Apu no sólo se representa como masculino, sino también como femenino; es decir, hay Apus hombres y mujeres. En unos casos, éstos llevan nombres femeninos como Nañantiyuk, Mama Simuna, Pukara Panti Lliklla, pero no necesariamente el nombre los describe como 
mujer sino la posición que tienen: el lado izquierdo — asociado a las mujeres, y el derecho a los hombres—; sin embargo, esto no es riguroso, puede ser lo uno o lo otro en ocasiones.

Por su parte, Pachamama es descrita como la generalidad de la tierra, que a su vez se divide en lugares particulares — chay hawakuna, ${ }^{5}$ esos lugares - y adquiere nombres masculinos o femeninos; no obstante, la masculinidad y feminidad no sólo se revelan por el nombre sino a través del sueño que adquiere la persona sobre el lugar. Pachamama es unidad y diversidad al mismo tiempo; es decir, "el término tiene una implicación fractal, igualmente aplicable a ambas situaciones" (Wagner, 2013: 87). Es como una hoja de papel cuadriculada, en el que la hoja representa la Pachamama y cada cuadrito un lugar específico y un nombre, pero ello es deforme y con subdivisiones y límites difusos. Así, las personas que brindan la ofrenda para alimentar a la Pachamama hacen un llamado con el $k^{\prime}$ intu de hojas de coca a cada lugar específico en el que han estado. Esto revela la complejidad de Apu y Pachamama, una noción distinta de territorio a la que plantea la perspectiva occidental (ver Torres Lezama, 2017). Este mismo hecho de la fractalidad de los lugares es también referido por Bruce Mannheim y Guillermo Salas (2015). Los autores comentan que los lugares tienen una calidad de fractalidad porque es común encontrar más y más nombres dentro de un lugar determinado. Por tanto, un lugar puede contener muchos lugares, que a su vez pueden contener más lugares (ver Mannheim y Salas, 2015: 63).

Estas entidades antropomórficas con intencionalidad -Apu y Pachamama- son descritas por Claudia Rosas (2014). La autora muestra un hecho específico sobre los estereotipos de la "bruja andina" perseguida por los inquisidores y extirpadores en la colonia:

... Juana Icha, india viuda y vieja del corregimiento de Canta, que es interesante porque describe su veneración a Apo Parato, considerado por el extirpador como el Demonio, quien la visitaba en las noches

\footnotetext{
${ }^{5}$ La palabra "hawa" más el pluralizador "kuna" hace referencia a los "lugares", pero también alude "afuera" o a las "afueras", además de "sobre" o "encima de". Así, la expresión chay hawakunapi purimushay — ve caminando en esas afueras, sobre esos lugares o en esos lugares— muestra el estar en el lugar.
} 
y tenía relaciones sexuales con ella, pero sobre todo le reclamaba alimento. Juana era curandera y comadrona, y su pacto con el supuesto Diablo Apo Parato — su huaca ["deidad"], en realidad — la ayudaba en su menester. Él se le presentaba bajo diferentes formas, algunas veces como un indio con su manta, y ella le daba chicha [cerveza de maíz], harina de maíz, mazamorra y coca, todos ellos elementos rituales de culto a las huacas (Rosas Lauro, 2014: 42-43).

Como dice en la cita, el Apo Parato - Apu — visitaba a Juana en las noches para tener con ella relaciones sexuales, hecho considerado por los extirpadores como diabólico. Este mismo suceso, la relación sexual entre la montańa y la especialista ritual, es descrito por Rozas Álvarez (1992) en la contemporaneidad. Dońa Ángela, la especialista ritual, dice:

Desde que me casé con el Apu y con mi mesal juntos caminamos por todo sitio curando a los enfermos, el Apu me reveló una vez y me sueño que siempre debería ser soltera para casarme con él; pero me casé, y a los pocos años mi marido se enfermó gravemente y murió. Por eso digo que el Apu es muy celoso, seguramente de mi marido tuvo celos y me lo quitó; desde la muerte de mi esposo no volví a casarme y tal vez por esta razón el Apu me da poder, puedo sanar enfermos graves, lo que a veces los médicos no pueden (Rozas Álvarez, 1992: 208).

Así, desde el prehispánico hasta la actualidad, las relaciones sexuales con los Apu y la Pachamama son indispensables para la iniciación del paqo, especialista ritual.

En este mismo sentido, Juan Bautista, un danzante de la peregrinación al santuario de Qoyllurit'i, me dijo:

La tierra te sueña como una señora o como una virgen; entonces nosotros decimos que la tierra nos está soñando. Y así, en este mes de agosto decimos que la tierra vive. Comienza a vivir y nosotros aún mantenemos nuestra costumbre y hacemos el alcance [ofrenda] con sahumerio y despacho [preparado de ofrenda], hacemos todavía esa 
nuestra costumbre... En nuestros sueños, a un Apu lo encontramos como un soldado o como un policía. Qoyllurit'i puede ser también un Apu y por eso nosotros le pedimos.

Como se puede ver en la experiencia del danzante, Apu y Pachamama se presentan en los sueños como personas, la Pachamama como una señora o virgen y el Apu como militar y policía.

Respecto a la apariencia antropomórfica de policía y militar que toman los Apu en los sueños femeninos, Cecconi y Crisóstomo (2007) la relacionan con el momento histórico del conflicto armado interno que se dio en Perú y su impacto imaginario onírico y mítico, cuyas transformaciones —estas nuevas apariencias de los Apu- serían reveladoras de la violencia real vivida por las mujeres:

Muchos sueños de mujeres hablan de encuentros con hombres desconocidos que intentan seducirlas, engañarlas y abusarlas. ¿Cómo se pueden interpretar estos sueńos? ¿Acaso éstos pueden revelar una realidad silenciosa que no encuentra otra manera de expresarse? El personaje principal de estos sueños seductores es el $A p u$ o el Urqu Tayta. En ocasiones, éste se parece a los hacendados y otras está vestido como militar. Éstas son transformaciones que parecen reflejar los cambios históricos de las identidades de los violadores. Estos son sueños y testimonios que dialogan entre sí. Los abusos reales de los hacendados y militares pueblan la esfera onírica y estos personajes son interpretados como manifestaciones del $A p u$... El $A p u$-militar parece representar un signo importante del impacto que tuvo el conflicto armado interno en el imaginario onírico y en el universo mítico. Los sueños también representan palabras a través de las cuales la violencia puede hablar. Los sueños no solo son utilizados como metáforas para hablar de una violencia absurda que no parece real, los sueños son ellos mismos revelaciones que nos pueden ayudar a aclarar la neblina donde la violencia se esconde (Cecconi y Crisóstomo, 2007: 76).

Como se mostró en las anteriores citas de Claudia Rosas (2014), Jesús W. Rozas (1992) y mis propios datos de campo sobre la peregrinación 
a Qoyllurit'i y Qhanqawani en Paucartambo, mis diálogos y prácticas compartidas con los paqo o especialistas rituales, la representación onírica de los Apu como militares, policías y otros, contrastan con la interpretación que presentan Cecconi y Crisóstomo (2007). Considero que estas autoras reducen y confunden los sueños con los Apu de las pobladoras — víctimas de la violencia_ y las violaciones sufridas durante la guerra interna en la década de los ochenta, atribuyendo a los Apu el papel de violadores por el hecho de que se representan en sueños como militares o policías. Además, cabe indicar que los Apu tienen una heterogénea e inestable identidad, como ya se comentó anteriormente.

De manera similar a los santos, vírgenes, Apu y Pachamama sueñan a una persona, ocurre con las almas —espíritus de personas muertas_ 6 de los familiares fallecidos; es decir, que las almas sueñan a las personas y no las personas sueñan con las almas. Por ejemplo, en la interpretación de los pobladores, "las almas siempre te hablan y te revelan a través de los sueños; a veces las almas dan mensajes específicos — "no hay que viajar", "desconfía de esta persona”, etc.- En otros casos, sus visitas son interpretadas como una genérica premonición de algo positivo o nefasto, dependiendo de la biografía onírica de cada persona" (Cecconi, 2013: 164). En ese mismo sentido, escuché un rumor en mi pueblo de Cachimayo-Anta; se trata de la muerte de la esposa de don Jeremías, ${ }^{7}$ quien no quiso que sus hijos cremaran a su esposa porque prefería que la enterraran, pero éstos no tomaron en cuenta la opinión de su padre y procedieron con la incineración. Pasados unos días el viejo hombre andaba triste en el pueblo contando a los familiares el sueño que había tenido con su esposa fallecida: "en mis sueños me ha dicho: 'acaso yo era tu enemigo, por qué me dejaste quemar”. Jeremías se enfadó con sus hijos y no quiso comer ni estar con ellos por esta causa. Así también, durante el viaje a Anta, pude escuchar en el bus el relato de una mujer que sońaba a sus parientes después de haber sido enterrada en el cementerio Jardines de la Luz: "estoy sintiendo frío”, les decía en

\footnotetext{
${ }^{6} \mathrm{Al}$ espíritu de la persona viva se le conoce más como animu. Aunque en algunos lugares también se usa para este mismo (ver Torres Lezama, 2017a).

${ }^{7}$ Cambié el nombre para proteger a la persona.

${ }^{8}$ Ubicado en el distrito de Poyoy, Cuzco.
} 
sueños a sus familiares. Y tras soñar repetidas veces, visitaron el camposanto y pidieron abrir la urna y vieron que estaba llena de agua. Así pues, en palabras de Arianna Cecconi, "los sueños y las visitas de las almas o de las diferentes entidades como el $A p u$-espíritu de los cerros_, la Pacha — la Tierra_y los Gentiles — ancestros_, así como la Virgen y los santos, no son descritas solo como visiones sino más bien como experiencias que dejan huellas en los cuerpos" (Cecconi, 2013: 167). Es decir, dan mensajes que en la vida real se pueden presenciar y hasta sentir en el cuerpo.

Ahora bien, me enfocaré en cómo sueñan los devotos y peregrinos a los santos y vírgenes, qué revelaciones reciben y cómo responden a estas manifestaciones oníricas. Carlos Flores Lizana recogió un testimonio del celador Juan de Dios Samochuallpa en 1991, en el que el Señor de Qoyllurit'i quería que le dieran culto:

El sitio donde se apareció el Señor era lugar de pastores y caminantes que entraban hacia las quebradas de Marcapata. Era un sitio donde se guarecían los pastores y los cazadores de vicuńas y de venados. Allí se refugió una mujer que se había escapado de Ocongate. Esta mujer estaba encerrada en la iglesia de Ocongate, y no sé cómo salió de ella, porque al día siguiente tenía que ser ajusticiada por su mala conducta. Llegó a este lugar donde está el Señor y se ocultó sin saber. En la noche mientras dormía se le apareció un Señor en sueño y le dijo que ese lugar se volvería en 'su casa'. El Señor era con vestido negro, pero con barba blanca y le entregó una carta con borde de oro para que se la llevara al cura párroco de Ocongate. La mujer que tiene este sueño se niega a ir a Ocongate por estar precisamente huyendo de la justicia. El Señor de los sueños insiste y la obliga a ir a Ocongate y entregar la carta con su mensaje correspondiente. Así es como se sabe que el Señor quería que se le dé culto en este lugar (Flores Lizana, 1997: 28-29). 
Foto 1. El santuario de Qoyllurit'i en el día central.

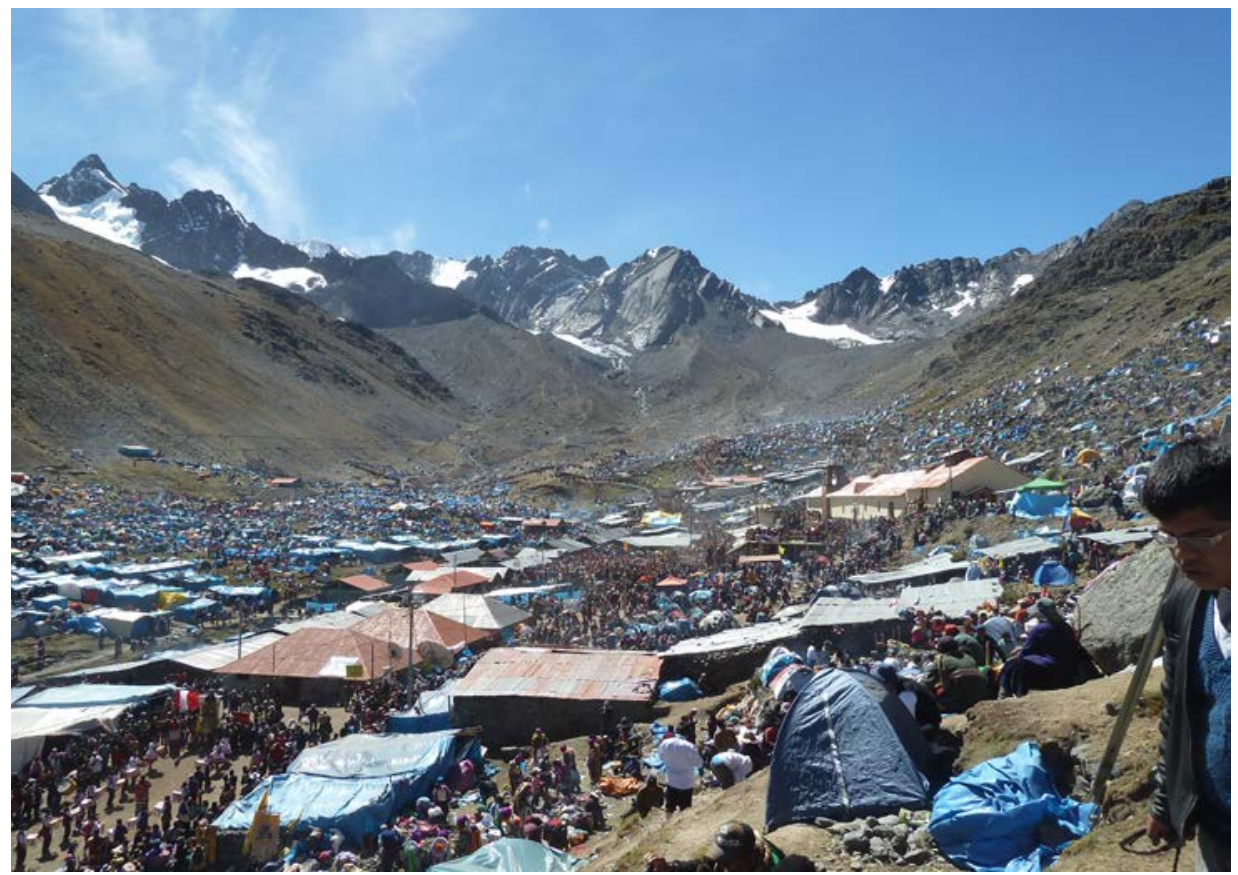

Fuente: imagen tomada por el autor en 2013

El sueño de la mujer nos muestra la apariencia que toma el Señor de Qoyllurit'i como un hombre de barba blanca y con vestido de color negro. El Señor le pide a la mujer que entregue una carta al párroco de Ocongate, pero ella se niega a llevar la carta porque precisamente había huido de la justicia. Ella es obligada por el Señor de Qoyllurit'i a llevar la misiva al sacerdote y así se sabe de la presencia del Señor y se inicia su culto. En el sueño de la mujer, el Señor de Qoyllurit'i se presenta como un hombre de edad, pero la leyenda de su origen da cuenta de la presencia de un nińo que se aparece al pastor Marianito Mayta. Un danzante de la peregrinación a Qoyllurit'i me contó que antes de viajar la primera vez el lugar, a sus 14 años, había soñado que estaba subiendo por el camino y se encontró con una cantidad de alpacas — camélido sudamericano- que eran vigiladas por un anciano, cuando preguntó al anciano/viejito por lo que hacia, éste le dijo que pastaba sus alpacas. Cuando el danzante fue al siguiente año al santuario recuerda que el 
lugar que recorría se parecía al de sus sueños. En numerosas ocasiones he oído a los danzantes referirse al Señor de Qoyllurit'i como "el viejo", de manera que el sueño del danzante con el viejo no era sino el Señor de Qoyllurit'i. Asimismo, escuché a uno de los peregrinos al santuario de Copacabana decir que el Señor de Qoyllurit'i sólo daba ganados, pero Copacabana entregaba en efectivo — dinero-. Así, el primer sueño del danzante presenta una imagen de un viejo pastor. De modo que es importante considerar que el Señor de Qoyllurit'i puede tomar la apariencia de una persona adulta y de un niño en el sueño de los peregrinos.

Otro ejemplo similar es la aparición del Taytacha de Qhanqawani, quien en la versión de los peregrinos es el mismo Señor de Qoyllurit'i que se cambia de lugar por las excesivas bullas y peleas de sus hijos. Así le había manifestado un niño a una mujer en los parajes silenciosos de Espinguni, T'otorani y Wankaqocha, en la provincia de Paucartambo. Don Anselmo Rojas, ecónomo y campanero del templo de Paucartambo, cuenta su sueño del siguiente modo:

Para que aparezca en Qhanqawani también, clarito a mí me ha revelado, ni siquiera conocía ese sitio, en mis sueños he aparecido en ese sitio. Y justo para que se haga su milagro, ahí había estado en ese sitio, un gringo, un señor gringo alto, con una barreta gruesa había estado empujando esa roca ... debajo del camino hay una roca ancha y plana, esa roca había estado empujando con su barreta. Yo le digo: “¿señor gringo por qué está empujando esta roca?”; me dice: "acá me voy a hacer mi casa” [en Qhanqawani]; yo le digo, pues: “¿y tu casa allá?” [se refiere al de Qoyllurit'i]; "ya no quiero vivir allá, acá voy a vivir tranquilamente”, me dijo; "ah ya", le dije. "Qué fuerza tiene para empujar esa roca, yo qué voy a poder”, dije. A ver, présteme su barreta, le digo, y me presta, la barreta pesaba mucho y no he podido levantar. "Atakau — qué miedo-, qué fuerza tendrás para empujar esta roca con el peso de esta barreta", le dije. Me dice: "ay, para mí no es nada". "Qué fuerza tendrás, takau", le dije. "Entonces vas a hacer tu casita, si voy a tener tiempo, voy a venir para ayudarte", le dije. "Ojalá, pues", me dice. Le dije: "sí, voy a venir, siempre va haber tiempito". Justamente, la plataforma he hecho 
yo, después hice la gradería para subir a sus pies. Luego estaba cavando para hacer la cimentación y he encontrado nieve ahí adentro al pie [del Señor]. A los que estaban trayendo piedras les he llamado: "vengan, mira acá adentro había habido nieve", les dije. "Cómo puede haber nieve aquí dentro si aquí en ningún lugar hay nieve", dijeron admirados. Yo les dije que buscaran en otros lugares también para que vieran si había nieve, en caso de que hubiera entonces no íbamos a creer, si no hubiera en ningún lugar no íbamos a dudar porque esto era una seña, una demostración que el Señor se ha venido con su nieve y está en el subterráneo su nieve. Entonces ya no podemos dudar diciendo si será él o no porque acá estaba su demostración; ahora tenemos que trabajar con toda fe, con toda voluntad, así dije. He arreglado, he hecho su chocita con paja, cumplí. Entonces digo para venirme: "Señor, he cumplido con mi compromiso, ahora como sea estarás acá, cuando tenga tiempito siempre estaré viniendo a visitarte". Ahora, otra vuelta me ha revelado, quiere que haga su casita más grande tal como estoy pensando, eso quiere. No hay tiempo por lo que estoy aquí [ecónomo], por eso le he dicho a Víctor Huamán: "preocúpate tú que eres celador de ahí también, preocúpate del Señor de Orqo Q'ara [montaña masculina - Qhanqawani], no te preocupes del Shina Q'ara [montaña femenina - Qoyllurit'i] no más. Preocúpate de él también, consigue gente y mejoraremos, yo voy a ir un rato a realizar la seña en qué forma vamos hacer, los voy a dirigir, las cositas que faltan yo voy a ayudar. La cosa es que consigas un maestro o personas para que hagan". No sé qué será, pues, hasta ahora no dice, ya no hay tiempo.

A don Anselmo, el Taytacha de Qhanqawani le ha revelado antes de que él conociera el lugar de su aparición. Le ha visto en sueños trabajar al Taytacha y ha cooperado con él en la construcción de su nueva casa. La apariencia que tomó el Taytacha fue el de un gringo (extranjero) con bastante fuerza. Don Anselmo cumple con la promesa que hizo en sueños y ayuda con la construcción de la nueva casa del Señor de Qoyllurit'i que se traslada a otro lugar y que toma el nombre de Qhanqawani. Además, el Señor de Qoyllurit'i le da otra evidencia de que es él mismo con la aparición de la nieve en el lugar donde se edifica su 
nueva vivienda (ver Torres Lezama, 2017b). Luego, Anselmo recibe otra revelación del Taytacha, esta vez le pide ampliar su casa, pero él no puede concretar el compromiso de su sueño porque no le alcanza el tiempo por su trabajo como ecónomo. Además, en otra ocasión, me contaron que un viejito había visitado a una familia de la zona llevando pan y le había invitado a su fiesta; tras la invitación el viejito había salido apresurado y en pocos segundos había aparecido en un lugar distante, los testigos de su visita no podían explicar cómo había logrado avanzar tanto en poco tiempo. Aquí es donde las experiencias del sueño y la vigilia se confunden; los hechos ocurren como en sueños y los sueños parecen reales: sutip'i hinaraq / musqhoypi hinaraq. Los compromisos del sueño son tan reales que se tiene que cumplir, tal como se cumple un compromiso concretado en la vigilia. Así, para Anselmo su sueño no es una ficción, sino algo muy serio y real.

Foto 2. Santuario de Qhanqawani y danzantes.

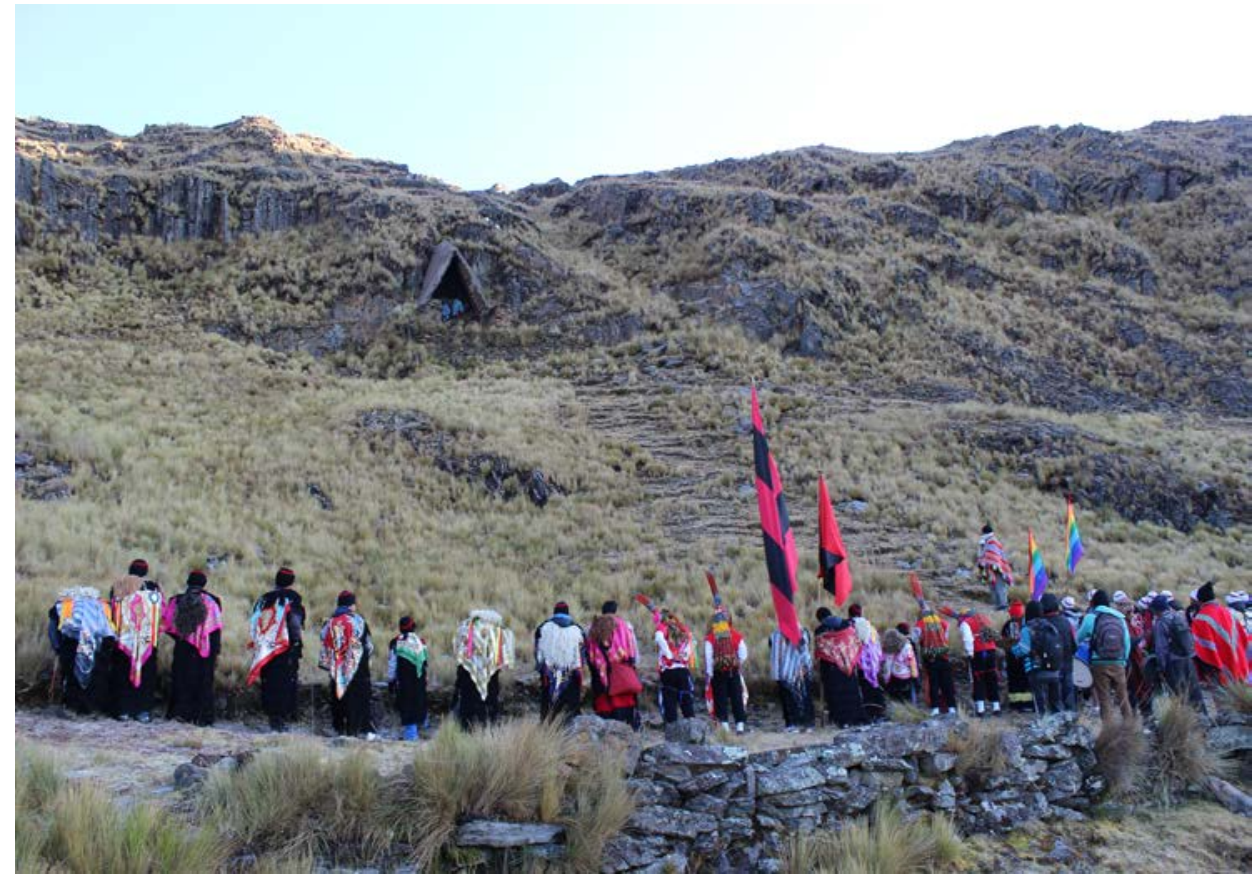

Fuente: imagen tomada por el autor en 2015 
Emerson, otro joven danzante y devoto de la Virgen del Rosario de Paucartambo me contó su revelación del modo siguiente:

Sí hubo una revelación de la Virgen ante mi persona, y ha sido la única porque de ahí no hubo más. Fue cuando ella se me apareció en mi sueño, mira que yo no sabía nada de la Virgen del Rosario, y alguna vez me invitó el señor Isaías Rojas y yo no acepté; "no, qué voy a bailar, no tengo tiempo", y así. Y en uno de esos días se me apareció la Virgen. Una señora con su ropa sencilla, me dijo: "hijo, báilame, por qué no me bailas, hijo. Mi pueblo me ha olvidado, estate conmigo, mira este mi pueblo me olvidó y por eso me siento triste, estate conmigo", me dijo. Entonces al día siguiente me desperté y dije: "qué es esto". Yo fui el primero en decir al señor Isaías que quería bailar. Es la primera vez que se me apareció la Virgen, me habló, hablé con ella, y de ahí [ya] no.

La Virgen se presenta en el sueño de Emerson como una mujer sencilla y le pide bailar para ella porque se siente olvidada por su pueblo. Ya que Don Isaías no pudo convencerlo para bailar, la Virgen lo motivó y Emerson aceptó la invitación sin mayor reproche. El hecho de que la Virgen le diga a Emerson que su pueblo la ha olvidado tiene que ver con el cambio del culto a la Virgen del Rosario, patrona de Paucartambo, por el culto a la Virgen del Carmen.

El poblado de Paucartambo fue fundado por los dominicos en 1622 y la parroquia estuvo consagrada a la Virgen del Rosario, ubicado inicialmente en la planicie de Llawllipata hoy Kallipata. Durante la colonia, la festividad de la Mamacha Rosario fue organizada por los españoles y luego realizada por los mestizos, pero con el transcurrir de los años los indios se apropiaron de la festividad por muchas décadas. Desde entonces los aborígenes festejaban a la Patrona a su manera y con danzas propias. Los españoles y mestizos, con el tiempo, quisieron retomar la festividad porque se quejaban de que ésta fuera desnaturalizada, o quizá por prejuicios étnicos criticaban la manera de celebrar de los indios. Estos enfrentamientos de grupos étnicos, de acuerdo con la memoria colectiva y los escritos sobre el hecho (Villasante, 1975, 1980; 
Authier (du), 2008, 2009; Flores, 2009), condujeron a entredichos, quejas y juicios que llegaron hasta el obispado de Cuzco.

Tras estos altercados, los espańoles y mestizos se dirigieron a otro culto mariano: la Virgen del Carmen. Fue entonces cuando a los indios, identificados con la Mamacha Rosario, les tocó protestar porque la nueva virgen recibía mayores honores que la patrona. Se dice que el conflicto entre estos dos grupos se agravó y llegó hasta el virrey y de ahí hasta el propio rey de España. El caso fue resuelto con la designación de la celebración de la Virgen del Carmen el 16 de julio para los vecinos del poblado de Paucartambo, y para los indios la Mamacha Rosario el 7 de octubre. De este modo, la festividad de la Mamacha Rosario quedó en manos de las comunidades campesinas y la celebración de la Virgen del Carmen a cargo de los mistis — mestizos-. Las rivalidades continuaron y en 1830 la Virgen del Carmen fue declarada patrona del pueblo de Paucartambo, en tanto que el culto a la Mamacha Rosario fue declinando con los años. Hasta 1960, la Mamacha Rosario fue festejada por los barrios de Q'enqomayu, Karpapampa y Camposanto, luego fue cayendo en el olvido. Pero tras las múltiples revelaciones de la Virgen a los pobladores, el culto fue retomado por los lugareños no hace más de una década y media y va en crecimiento conforme transcurre el tiempo. Y como ocurrió antańo, los que celebran a la Virgen del Rosario son jóvenes y devotos que viven en Paucartambo, mientras que los que celebran a la Virgen del Carmen, la fiesta más pomposa, son en su mayoría migrantes que retornan de distintas partes del país para la fiesta.

Don Anselmo Rojas, fiel devoto de la Virgen del Rosario, indica que los mayordomos dejaron de tener interés en realizar la fiesta y se tironeaban la demanda, pero casualmente unas señoras le hablaron a él para tomar la mayordomía porque sabían que era devoto, aceptó y se empeñó en continuar con la fiesta, desde entonces ha ido impulsando la celebración. Después de que el culto se retomó, después de años, la Virgen soñó a don Anselmo:

Cuando me han entregado el templo [ecónomo], en mis sueños, clarito me ha revelado a mí. En mis sueños estaba abriendo la puertita [puerta 
pequeña del templo] y delante del altar había estado parada una señora alta, entonces me he asustado: “¿Cómo he cerrado a esta señora! ¿Qué me dirá? ¿Irá a quejarse?”. A mí no me ha dicho nada, sino a la otra virgen del altar, que estaba parado delante del altar, ella sería, pues no. Entonces, hay otra virgen aquí abajo, en el costado, a ella le ha llamado, a mí no me ha dicho nada, ven, bájate, vamos a conversar diciendo. Y se bajan las dos [Vírgenes Rosarios ${ }^{9}$ de sus altares], cuando se bajan, yo dije: "ay, las vírgenes habían sabido bajarse, aquella virgen que está parada allá no será gente sino la virgen de arriba del altar", miro arriba y su altar estaba vacío. Entonces, dije: “jay, la virgen había sido, ayyyyy! ¿Ahora qué hago? ¿Qué cosa voy a hacer? ¿Ahora cómo lo voy hacer subir a su altar ahora? Qué voy a poder [solo], a alguien me suplicaré", estuve pensando. Entonces, la otra virgen que se ha bajado se ha acercado y ahí la otra virgen de arriba le ha dicho: "ahora sí, recién estamos recordadas, tantos años olvidadas, despreciadas", le ha dicho. Entonces, dije: "tiene razón de aclarar; sí, pues, tantos años", seguirán conversando, me regresé. En la mañana, bajo con ese pensamiento: "las vírgenes estarán pues ahora en el suelo", a alguien me suplicaré para que me ayudé a subirlas; cuando entré [al templo], normal estaba todo, sólo he tenido que rezar [ríe de su sueño].

Las dos vírgenes del Rosario conversan entre ellas en el sueño de Anselmo, el campanero y ecónomo del templo de Paucartambo; hablan sobre su culto y el interés que toman en ellas sus devotos. ${ }^{10} \mathrm{El}$ reclamo que le dice a Emerson, danzante: "mi pueblo me ha olvidado", se confirma en el sueño de Anselmo: "ahora sí, recién estamos recordadas, tantos años olvidadas, despreciadas". Para don Anselmo su reclamo parece ser justo porque realmente han estado olvidadas por mucho tiempo, razón por la cual también decidió realizar el cargo y motivar a más personas a seguir con el culto. $\mathrm{Y}$ otra de sus devotas en un momento dijo: “ $¡ Y$

\footnotetext{
${ }^{9}$ Hay dos vírgenes del Rosario en el templo, una es movible, grande, y está en una urna en la pared del lado izquierdo; la otra es pequeña y está ubicada en medio del altar del templo.

${ }^{10}$ Cada virgen del Rosario tiene la intención de actuar por separado, este mismo hecho he oído hablar de las demandas del Taytacha de Qoyllurit'i en la nación Anta. Una de las demandas tenía más suerte que la otra, porque cuando lo llevaban siempre encontraban gente para comprometer o hacer la hurk' $a$ a los devotos para que colaboren con diferentes donaciones.
} 
por qué la gente no te quiere a ti, mamita?”, y al ver el desinterés por la Virgen ella asumió la mayordomía.

Ahora bien, la revelación de la Virgen del Rosario no sólo se da en los sueños, sino que también es algo que la Virgen cumple a sus devotos, que se concreta en la vida real. Así me contó Marcelino, danzante de la festividad de la Virgen:

La última revelación que le puedo decir, en el aspecto emocional, yo le he pedido de todo corazón, le he pedido a Dios, le pedí a la Virgen de Carmen, le pedí a la Virgen del Rosario. "Virgencita Rosario quiero alguien que me quiera de verdad, quiero una pareja de verdad, no me importa quién sea, cómo sea, pero dame, envíame, yo le pido de corazón". Yo le conté a ella [mi pareja], la verdad es la verdad, es un milagro que ella y yo hayamos congeniado como pareja. Cada vez cuando tenemos algún disgusto decimos: "la virgencita nos ha unido", tratamos de hacer las cosas con diálogo. La virgencita es testigo de lo que yo le pedía: "virgencita, envíame a alguien, quiero alguien que me quiera de verdad", le he pedido de todo corazón y se ha hecho posible y yo era devoto de la Virgen [del] Rosario. Ya, yo dije: "no importa quién sea, cómo sea, no me importa que tenga sus hijos o no tenga sus hijos, no me interesa, sólo quiero un amor perfecto para mí, que sólo sepa el valor, que me quiera como persona, eso es lo que yo quiero", y verdaderamente hasta ahorita yo digo gracias a la Virgen del Rosario.

La Virgen del Rosario cumple con Marcelino, también él se empeña en danzar en su fiesta y llevarle velas cada vez que puede. Cuenta que en un momento la Virgen le sanó su hombro después de que se atrevió a cargarla con el hombro herido. Marcelino agradece a la Virgen por haberle unido con su pareja actual, y cuando se produce algún altercado con su esposa recuerda su pedido a la Virgen, dice: "la virgencita nos ha unido", y trata de apaciguarse.

De manera similar, la Virgen Asunta de la Provincia de Calca se presenta a sus devotos en sueńos y ayuda a resolver sus problemas, y también pide que se interesen en celebrar su fiesta. Jesús W. Rozas (2009) recopila en Calca el siguiente relato: 
Cuando una no tiene dinero para alimentar a sus hijos, debe ir donde la Virgen Asunta a rezarle. Una mujer tenía su maizal, que fue afectado por el puka puncho [enfermedad del maíz], y corría el riesgo de no cosechar un solo grano. La mujer, en su desesperación, no teniendo dinero ni maíz para hacer comer a sus hijos, fue a la iglesia a orar donde la Virgen, y lamentó su desgracia delante de la imagen, ¿por qué tenía que tener este castigo?, si ella no molestaba a nadie; lloraba con mucha tristeza. Esa noche, en sus sueños, la Virgen se presentó y le dijo: "no llores, de tu chacra [parcela con cultivo] vas a cosechar bastante maíz, venderás en un buen precio y con el dinero, vas hacerme cargo para mi fiesta". Despertó muy asustada diciendo, "si no tengo dinero, la Mamita todavía me pide que haga su cargo". Dudando mucho y muy triste con lo que había sońado, fue a su chacra y vio con sorpresa que su maíz no tenía puka puncho, y cada planta producía un buen fruto. La mujer cosechó ese año bastante bien, vendió a un buen precio el maíz y celebró el cargo a la Mamita, y hoy tiene un sitio en el mercado donde vende productos agrícolas que rescata, y sus hijos están estudiando en el colegio (Rozas Álvarez, 2009: 88-89).

Tras sus oraciones a la Virgen, la mujer sueña con ella y le dice: "no llores, de tu chacra vas a cosechar bastante maíz, venderás en un buen precio y con el dinero vas hacerme cargo para mi fiesta". La Virgen ayuda a la mujer y al mismo tiempo le pide pasar la mayordomía, por eso muchas veces los mayordomos suelen decir: "la Virgen hace solita su fiesta”, cuando la virgen o el santo cooperan con la realización de la fiesta dando facilidades a los mayordomos. Pero, así como la Virgen cumple con su ofrecimiento, exige que los devotos cumplan porque si no viene el castigo y a veces la muerte. Por ejemplo, "Ningún cargador [del Patrón de San Sebastián del Cuzco] puede salir de la cuadrilla de San Sebastián sin exponerse a que el 'capitán' aparezca en sus sueños, vestido con traje de gala militar, con gesto adusto reclamando airadamente su falta de lealtad" (Millones, 2005: 31). Del mismo modo, cuando viajé por primera vez al santuario de Qoyllurit'i en el año 2001, la señora Juana, con quien nos acompañamos, me contó sobre la apertura de la vía carrozable hasta el santuario, es decir, de 
los ocho kilómetros restantes. Cuando comenzaron a trabajar el tramo con maquinarias pesadas el ingeniero de la obra había recibido una amenaza del Taytacha en sueños: "si vas a abrir la carretera te vas a morir", tras esta advertencia el ingeniero desistió de la obra y ahí quedo el proyecto. También indican que las maquinarias se malograban a menudo durante el trabajo. Estos hechos cuentan los peregrinos con frecuencia, advirtiendo lo que puede ocurrir si se provoca con acciones no admitidas al mismo Taytacha.

Así pues, cuando los peregrinos y devotos recuerdan sueños amenazantes y desgracias en sus vidas suelen decir: "el Señor es castigoso". Por ejemplo, Carlos Flores (1997) recoge la experiencia de un vecino de Pirque que ocurrió ya hace varias décadas atrás. N. Villa se había dirigido a los lavaderos de oro de Quincemil con deseos de extraer el metal y mejorar su condición económica. Sin embargo, no todos sus planes se dieron como esperaba y tuvo que pedir al Taytacha para que intercediera en su desgracia. Tras sus imploraciones al Taytacha el hombre logró tener prosperidad en su trabajo, y en agradecimiento a la buena fortuna recibida el hombre decidió colaborar con la mejora del santuario.

De acuerdo ya con lo expuesto anteriormente, el párroco señor Mujica se dirigió a la ciudad del Cuzco con el fin de contratar con el escultor Fabián Palomino para que aclare las señas que aparecían en la peña de la capilla del Señor de Ccoillor-ritte, habiendo convenido para un día designado el viaje al santuario, que debía ser por tren hasta Urcos y de este sitio a caballo. En víspera del día determinado para el viaje, Palomino se acordó y resolvió no viajar por tener muchos compromisos que cumplir en su profesión de escultor, y se acostó manifestando esta resolución a su esposa; en la madrugada casi al amanecer, Palomino dio gritos desesperados y la esposa le hizo despertar para saber el motivo, a lo que manifestó que un caballo blanco quería victimarlo recalcando por qué no había querido visitar; esta revelación hizo recordar el compromiso del viaje y al rayar el día hizo levantar a la esposa y la envió a la casa designada por el señor Mujica con el fin de averiguar si había llegado para el viaje, y habiendo constatado que se hallaba presente se 
alistó a la ligera para el viaje en tren, que es a las siete de la mañana (citado por Flores Lizana, 1997: 34).

Como se puede ver, Fabián Palomino, el escultor, recibe un escarmiento en sus sueños: "un caballo blanco quería victimarlo recalcando por qué no había querido visitar". Tras este sueño decide cumplir de inmediato con el cometido: aclarar las señas que aparecían en la peña de la capilla del Señor de Qoyllurit'i.

Los peregrinos que conocen de las implicaciones del incumplimiento con los santos y vírgenes procuran llevar adelante su compromiso. Es el caso de Felipe, poblador de Caicai, que entregó el cargo o mayordomía a otra persona, pero por sueños supo que el mayordomo entrante no iba cumplir con el cometido.

Nuestro padre Qhanqawani me dijo, faltando dos días, nosotros nos organizamos, pero con el querer de nuestro Señor estamos cumpliendo, en mi sueño me dijo: "hermano, no hagas secar esta planta", y yo no he comunicado a nadie y he preferido tenerlo en mi corazón y me entristecí... tomando en cuenta mi sueño, dije a mis compañeros: "vamos y vamos", como sea vamos. Faltando dos días nos organizamos y estamos acá. Pensando, dije: "creo que estos carguyoq no van a cumplir", entonces "tomemos fuerza", dije, "no quedemos atrás". Hermanos míos, yo les suplico, para el próximo año yo estoy de cargo de la danza qhapaq qolla. Al próximo año estaremos como una sola persona.

El Taytacha de Qhanqawani le pide a Felipe "no hacer secar la planta", es decir, el peregrino entiende la frase como una advertencia para no dejar la mayordomía de la danza ahí por culpa del incumplimiento de uno de sus devotos. De manera que él toma con seriedad su sueño y motiva a sus compañeros a participar en la peregrinación sí o sí. Ante la irresponsabilidad del mayordomo entrante, Felipe asume nuevamente el cargo - mayordomía - para no "hacer secar la planta" que sembró. Además, se comprometió a participar con su grupo de danza "como una sola persona”; es decir, que todos los integrantes, al contribuir con el grupo, se disuelven en la unidad. 
Así como Felipe se comprometió con el Taytacha Qhanqawani, yo también, como danzante pablo y luego como wayri, me comprometí para apoyar con los afiches y programas para la fiesta. Después de haber retornado de la peregrinación de Qoyllurit'i en junio de 2016, soñé que estaba cerca de una carpa de venta de víveres ya a la puesta del sol, un tanto oscuro, cuando de repente vi venir a un colega que se sentó a mi lado, todo preparado para el viaje a Qhanqawani. El antropólogo me dijo: "ya estoy yendo a Qhanqawani”, y yo, muy desubicado, pregunté: “¿ya es la fecha?” Mientras, me decía a mí mismo: "yo no he hecho el afiche, tendré que ir para hacerlo y los hago alcanzar". Y tras este sueño me apresuré en diseñar el afiche y preparar el programa para presentar al celador y los danzantes para que dieran visto bueno y así cumplir con mi compromiso. Obviamente que para la fecha de fiesta del Taytacha de Qhanqawani faltaban aun dos meses —agosto-, pero mi sueño me exigía cumplir con el compromiso con anticipación. Comenté mi sueño a los devotos en la reunión que tuvimos para revisar la historia y el celador me dijo: "el viejo es terrible" ${ }^{11}$, haciéndome saber que es castigoso para con la gente que le falla. Y como el Taytacha Qhanqawani es el mismo Taytacha Qoyllurit'i que se mudó de lugar, entonces por ello también le dicen "el viejo".

El Niño Compadrito es otro ejemplo descrito por Abraham Valencia (2007) que muestra el castigo del Santo Niño al arzobispo de Cuzco. En la década de 1980, el monseñor Luis Vallejos Santoni proscribió el culto al Niño Compadrito por no formar parte del panteón católico, dentro del proceso de evangelización en la arquidiócesis a todo nivel y en toda su extensión. Así, la Iglesia católica comenzó con la persecución al Niño Compadrito, pero sus devotos, en su mayoría mujeres, lograron custodiarlo como buenos fieles. Sin embargo, tras sus fatigadas maniobras de protección le rogaron al Niño hacerse justicia con la siguiente oración:

Niño Compadrito, abogado, doctor, padre nuestro, tú que eres bueno y malo, tú que puedes hacer y ordenar las cosas, tú que tienes poder sobre los hombres... ¿por qué no castigas ya a tus verdugos? ... ¿Hasta

\footnotetext{
${ }^{11}$ Se refería al Taytacha Qoyllurit'i, así también lo llaman otros danzantes.
} 
cuándo nos vas a hacer sufrir para adorarte? Venimos sigilosamente como si hubiéramos cometido algún pecado, de una vez sacúdete de tus enemigos y destrózalos (Valencia, 2007: 257-258).

De acuerdo con Valencia:

Otros fieles afirmaban que estaban en continuo contacto con el Nińo Compadrito porque se les presentaba, tanto cuando estaban despiertos como cuando sońaban, indicándoles que no se preocupasen, recomendando para que no hicieran ninguna acción en su defensa y que sólo esperasen con humildad sin impaciencia las decisiones del Todopoderoso. Otros devotos, afirmaban que el Nińo estaba sufriendo demasiado, porque en sus sueños se les había presentado como un niño resignado y harapiento y que era necesario liberarlo, pase lo que pase y que a la vista también el obispo se ponía tolerante en su saña de extirparlo (2007: 258).

Aquel día de justicia llegó para los devotos del Niño Compadrito tras algunas semanas de su pedido sucedió el accidente. Un día martes por la mañana "fallece el monseñor Luis Vallejos Santoni, cuando el vehículo en que viajaba rodó a un abismo, aproximadamente de 300 metros de profundidad, a 4 kilómetros de la comunidad de Chuta, distrito de Limatambo de la provincia de Anta" (Valencia, 2007: 258). Como se puede ver, el santo o la virgen es capaz de acabar con la vida de una persona si es que ésta incomoda su culto o incumple con sus promesas, por eso los devotos toman en serio sus sueños.

\section{Ideas finales}

Por un lado, he mostrado una serie de expresiones en quechua referidas al dormir y al sueño con el propósito de dar a conocer el entendimiento local sobre el mismo. Así, he expuesto que la palabra "sueño", en quechua musqhoy, no implica dormir como ocurre en el español; puñuy es la palabra que hace referencia a la acción de dormir. Además, esta acción de dormir es entendida entre los quechuas del Cuzco como algo "externo" que conduce al cuerpo a dormir. Si tomamos en cuenta el 
santuario del sueño en el periodo prehispánico, podemos ver que había una entidad que les permitía acceder a un buen sueño. Pero no tengo la pretensión de resolver el problema en este trabajo, sino que sugiero tomar en cuenta la expresión quechua: puñuy aysawashan — me lleva el sueño- y sus variantes, para tener mayor entendimiento de éste. Del mismo modo, he mostrado que los sueños no son vistos como "buenos o malos" entre los quechuas, sino como "feos y bonitos" — millay, munaycha-, y en castellano los pobladores usan la expresión "he soñado bien feo" antes que "malo". Por último, me he referido a las expresiones sut'ipi hina —en verdad/realidad—y musqhoypi hina —en sueño-, diciendo que no son antagónicas, sino analógas. Un acontecimiento inexplicable en la vida puede ser referido como musqhoypi hina, y una serie de imágenes en los sueños puede vivirse como sut ipi hina. Es decir, que las experiencias de la vida a veces pueden ser como un sueño y las imágenes de los sueńos pueden parecer una realidad/verdad.

Por otro lado, he expuesto testimonios de devotos y peregrinos sobre revelaciones de santos y vírgenes. Los santos y vírgenes, al igual que Apu y Pachamama, se manifiestan en los sueños como personas: militar, policía, niño, viejo, mujer, etc.; es decir, que su identidad es inestable, heterogénea y no absoluta. Sońar con la representación de los santos y vírgenes es de buen augurio para los devotos, pero si son sońados como bulto de santos y vírgenes son entendidos como qhencha o de mal augurio porque representan desgracia o muerte. Asimismo, entre los pobladores del Cuzco, los santos y vírgenes sueñan a las personas y no las personas sueñan a ellos; les piden ser parte de su culto, les invitan a bailar en su fiesta, les ayudan a resolver sus problemas, les ayudan a mejorar su salud, a encontrar una pareja, les ayudan a organizar su fiesta, entre otros. Estas revelaciones son tomadas como sut $i$-verdad- por los devotos y las promesas son cumplidas porque el incumplimiento conlleva a la desgracia y la muerte. De manera que los peregrinos y devotos que conocen de este hecho procuran no enfadar a los santos y vírgenes con sus actitudes irresponsables y agresivas — como el caso del monseñor-. Finalmente, muchas de estas revelaciones pasan del plano individual y familiar a uno colectivo, y de este modo contribuyen al tejido de la historia del santo o la virgen que se transmite oralmente entre los devotos. 


\section{Bibliografía citada}

AMLQ-Academia Mayor de la Lengua Quechua, 1995, Diccionario

Quechua-Español-Quechua, Municipalidad del Qosqo, Cuzco.

Andrade Ciudad, Luis F., 2005, Aguas turbias, aguas cristalinas: el mundo de los sueños en los Andes surcentrales, PUCP, Lima.

Authier (du), Martine, 2008, Un genio popular. Historia de vida de David Villasante González, CBC-IFEA, Cuzco.

Authier (du), Martine, 2009, Fiesta Andina. Mamacha Carmen en Paucartambo, CBC, Editorial San Marcos, Lima.

Bauer, Brien, 2016, El espacio sagrado de los incas. El Sistema de ceques del Cuzco, CBC, Cuzco.

Cecconi, Arianna, 2013, “Cuando las almas cuentan la guerra. Sueños, apariciones y visitas de los desaparecidos en la región de Ayacucho", en Ponciano del Pino y Caroline Yezer (editores), Las formas del recuerdo. Etnografías de la violencia politica en el Perú, IEP, Lima.

Cecconi, Arianna y Mercedes Crisóstomo, 2007, "La violencia en las mujeres. Entre la realidad y los sueños”, en https://www. academia.edu/20316798/_La_violencia_en_las_mujeres._ Entre_la_realidad_y_los_sue\%C3\%B1os_

Flores Lizana, Carlos, 1997, El Taytacha Qoyllur Riti, Instituto Pastoral Andina, Sicuani, Cuzco.

Flores Ochoa, Jorge A. et al., 2009, Cuzco. El lenguaje de la fiesta, BCP, Lima.

Kato, Takahiro, 2001, "Historia tejida por los sueños: formación de la imagen del niño compadrito", en Hiroyasu Tomoeda, Luis Millones y Takahiro Kato, Dioses y demonios del Cuzco, Fondo Editorial del Congreso del Perú, Lima.

Mannheim, Bruce, 2015, "La historicidad de imágenes oníricas quechuas sudperuanas", Revista Letras, vol. 86, núm. 123, pp. 5-48, Lima.

Mannheim, Bruce y Guillermo Salas, 2015, "Wak'as entifications of the Andean Sacred", en Tamara L. Bray (editora), The archaeology of wak'as. Explorations of the sacred in the Pre-Columbian Andes, University Press of Colorado. 
Millones, Luis, 2005, "De las Siete ciudades de Cíbola a la urbe indiana: apuntes para una historia de los santos patronos", en Luis Millones (editor), Ensayos de historia andina, UNMSM, Lima.

Pitarch, Pedro, 2013, La cara oculta del pliegue. Antropología indígena, Artes de México, Conaculta, México.

Rosas Lauro, Claudia, 2014, "Curanderos, chamanes e idólatras en los Andes coloniales", en Luis Millones y Silvia Limón (coordinadores), Iluminados, hechiceros y sanadores. Prácticas y creencias en Perú y México, UNAM, México.

Rozas Álvarez, Jesús W., 1992, “Sana, Sana Patita de rana...”, en Hiroyasu Tomoeda y Jorge A. Flores (editores), El Qosqo. Antropología de la ciudad, Ministerio de educación del Japón, CEAC, Cuzco.

Rozas Álvarez, Jesús W., 2009, “Una fiesta de rompe y raja: El significado de la fiesta religiosa en el catolicismo popular", en Jorge A. Flores (editor), Celebrando la fe. Fiesta y devoción en el Cuzco, CBC, UNSAAC, Cuzco.

Strathern, Marylin, 1988, The gender of the gift. Problems with women and problems with society in Melanesia, University of California Press.

Torres Lezama, Vicente, 2017a, "Cuerpo, animu y alma como integridad en la persona andina”, en Vicente Torres y Víctor Anguiano (coordinadores), Recuperando la vida. Etnografias de sanación en Perú y México, Ríos Profundos Editores, Lima.

Torres Lezama, Vicente, 2017b, "El taytacha Qoyllurit'i como sujeto", en prensa.

Valencia Espinoza, Abraham, 2007, Cuzco Religioso, INC, Cuzco, Lima.

Villasante Ortiz, Segundo, 1975, Paucartambo: Visión monográfica, Tomo II, Editorial León, Cuzco.

Villasante Ortiz, Segundo, 1980, Paucartambo: provincia folklórica. Mamacha Carmen, Tomo II, Editorial León, Cuzco.

Wagner, Roy, 2013, "La persona fractal", en Montserrat Cañedo (editora), Cosmopolíticas. Perspectivas antropológicas, Editorial Trotta, Madrid. 